\title{
Microbial biodiversity as related to crop succession and potato intercropping for management of brown rot disease
}

\author{
N. A. S. Messiha ${ }^{1,2^{*}}$, K. M. A. Elhalag ${ }^{1,2}$, N. M. Balabel ${ }^{1,2}$, S. M. A. Farag ${ }^{2,3}$, H. A. Matar ${ }^{2,3}$, M. H. Hagag ${ }^{2,3}$, A. M. Khairy ${ }^{2,3}$, \\ M. M. Abd El-Aliem², E. Eleiwa ${ }^{2,3}$, O. M. E. Saleh ${ }^{2,3}$ and N. S. Farag ${ }^{1}$
}

\begin{abstract}
Potato brown rot, caused by Ralstonia solanacearum, ranked globally as the second most important bacterial plant pathogen. In the present study, the influence of different cropping programs in potato brown rot management was investigated in four infected fields in Egypt. Two districts were selected as sandy soils in Giza (Wardan) and Behera (Ganuob El-Tahrir) governorates. The other two were selected as silty clay in Minufyia (Talia) and Beni-Suef (Sids) governorates. The followed crop succession included corn, potato intercropped with cabbage, onion, cowpea, wheat, corn again, and ended by potato. The pathogen was undetectable after corn, onion, and wheat. It decreased in cowpea and cabbage rhizospheres in the clay soils. The pathogen was undetectable at all districts, except at Sids, where the pathogen was significantly decreased but was not eradicated. This was possibly attributed to the high ratio of $\mathrm{NO}_{3}{ }^{-}$and $\mathrm{Na}^{+}$at this district. Decreased $R$. solanacearum density after corn coincided with the high ratio of fluorescent pseudomonads, endospores, and actinomycetes, being most clear in the poor soils (Wardan) and less clear under iron excess at Ganoub El-Tahrir as well as the clay soils. Corn rhizosphere supported an array of antagonistic actinomycetes such as strains similar to Streptomyces intermedius, Streptomyces albidoflavus group, Streptomyces argenteolus group, and Streptomyces erythrogriseus. Intercropping potato with cabbage decreased the density of the pathogen in rhizosphere, which is associated with greater antagonistic fluorescent pseudomonads, Bacillus spp. and Serratia spp. Onion soil and rhizosphere associated with abundance of antagonists and fluorescent pseudomonads, followed by S. maltophilia and Bacillus spp. Wheat soil and rhizosphere supported fluorescent pseudomonads and antagonistic Streptomyces spp., especially in sandy soils. The pathogen was undetectable after planting the ending potato in the three districts, Wardan, Ganoub El-Tahrir, and Talia. This was accompanied by a general oligotrophism and increased ratio of fluorescent pseudomonads, endospores bacteria, and actinomycetes along with a diversity of $R$. solanacearum antagonists such as S. maltophilia, Citrobacter freundii, Acinetobacter sp., Delftia sp., and Serratia marcescens.
\end{abstract}

Keywords: Bacterial wilt, Ralstonia solanacearum, Bacteria community, Disease incidence, Antagonists

\section{Background}

Potato is the second most economically important crop after citrus in Egypt. Potato brown rot disease is the most serious threat to the pan world trading of potato. It is a systemic bacterial wilt disease caused by Ralstonia solanacearum race 3 biovar 2 (Yabuuchi et al. 1995). $R$.

\footnotetext{
*Correspondence: nevein_messiha@yahoo.com

'Bacterial Diseases Research Department, Plant Pathology Research Institute, Agricultural Research Center (ARC), Giza, Egypt

${ }_{2}^{2}$ Potato Brown Rot Project, Ministry of Agriculture, Dokki, Giza, Egypt

Full list of author information is available at the end of the article
}

solanacearum is subdivided into five races on the basis of host range and five biovars on the basis of catabolic properties (Hayward 1991) and more recently as Phylotype II, sequevar 1 for potato race on the basis of genetic sequencing (Prior and Fegan 2005). According to FAO and EU regulations, potatoes for exportation must be produced in pest-free areas (PFAs) mostly located in the newly reclaimed areas (NRAs). Meanwhile, controlling the disease in old potato fields is a complicated task, and single management regime showed limited success (Karim and Hossain 2018), in addition to the hazardous 
environmental impact. A study on the survival of the pathogen in Dutch versus Egyptian soil(s) was investigated and compared by Messiha NAS (2006) where survival of the pathogen and disease management was attributed to physical, chemical, and microbial factors.

Biocontrol by means of Pseudomonas fluorescen, Bacillus sp., Erwinia sp., and a Hrp-mutant of $R$. solanacearum were relatively ineffective for controlling the pathogen under field conditions (Ran et al. 2005). The failure may be attributed to the inability of the introduced biocontrol agent to establish itself in the new environment. For example, excess iron in soil may explain such failure (Hoitink and Boehm 1999). The biocontrol agent may fail to establish itself due to competition by native microbial community, especially in organically managed soils with greater diversity of microbial community (van Bruggen and Termorshuizen 2003). For these reasons, sustainable disease suppression mechanisms are required to ensure establishment of the biocontrol agents in soil. One of these mechanisms is shifting the native microbial community towards greater suppression and greater antagonism against $R$. solanacearum gradually (Gorissen et al. 2004). This can be achieved by fertilization regimes and/ or crop rotation. Crop rotation and succession is one of the cultural practices for pest management and improvement of the soil structure (Stanger and Lauer 2008). Crops such as maize, wheat, barely, oat, onion, garlic, and cabbage have also been used in different combinations to suppress pathogen levels within the soil (Reddy 2017). Several factors such as the ability of the pathogen to survive in the absence of host, climatic conditions, and soil type are among the factors to be considered in disease control (Jones and Barbetti 2012). Intercropping can be also employed to decrease the incidence of bacterial wilt as well as root-to-root transmission of the pathogen. Corn and cowpea were proven to be the most effective intercrops in the Philippines (Hayward 1991). Mwaniki et al. (2017) noted that the pathogen population decreased after planting non-host crops such as lablab and garden pea. $R$. solanacearum remained at detectable levels after a single or double cropping of non-host plants. Planting more than two non-host crops in any combination is necessary to bring the population to very low level. Katafiire et al. (2005) claimed that the rate of disease incidence was lower following wheat, maize, carrots, sorghum, or phaseolus beans rotation. The effect of crop rotation and weed control was associated by a decline in soil population of $P$. solanacearum. The decline of the pathogen in maize rhizosphere was attributed to an increase in population of Pseudomonas cepacia, which was antagonistic to $P$. solanacearum in vitro. Lemaga et al. (2001) found that a one-seasonal rotation significantly decreased wilt. The crop sequences mostly used were potato-onion-potato, potato-peas-potato, potato-cabbagepotato, potato-sweet potato-potato, potato-millet-potato, potato-carrots-potato, potato-beans-potato, and potatopotato-potato. Planting two different crops in two consecutive seasons resulted in superior wilt control than planting the same crop consecutively.

Sharma and Kumar (2004) studied the disease management by starving the bacterial pathogens in soil. Eleven different crop combinations were followed in the rotations in sick soil. The decrease in $R$. solanacearum was highly significant in rotations ragi-French beanokra, okra-maize-radish, maize-carrot-cucumber, and maize-spinach-watermelon.

In the present study, different cropping schemes were evaluated for their efficacy in suppression of the disease. The relation between each crop and disease management was evaluated in relation to soil chemical and microbial characteristics.

\section{Materials and methods}

The effect of crop successions on potato brown rot incidence/suppression was evaluated. The crops included corn, potato intercropped with cabbage (Additional file 1), onion, cowpea, wheat, corn (maize), and potato.

\section{Field sites}

Four naturally infected districts with $R$. solanacearum at different governorates in Egypt were selected to conduct 3 years crop succession experiments. Two districts were sandy (Wardan and Ganoub Eltahrir) and two were clay (Talia and Sids). Ganoub Eltahrir was severely infected; Talia and Sids were moderately infected, while Wardan was slightly infected. Severe infection was also detected in some left potato plants and leftover potato tubers, especially in the old potato districts at Talia and Sids. The sprinkler irrigation was used at Wardan and Ganoub Eltahrir fields, while at Talia and Sids, it was through usual canals. Physical and chemical characteristics of each soil from the selected fields were determined before starting the crop rotation regime.

\section{Physical and chemical soil characteristics}

Physical and chemical characteristics were determined at the Agricultural and Biological Research Department, National Research Centre (NRC) (Cairo, Egypt), at the beginning of the crop succession program. Fractionation of soil particle sizes was determined according to Bouyoucos (1927). Soil extract (1:2.5 soil to water) was made to determine the macro- and micro-elements, $\mathrm{N}$ $\mathrm{NO}_{3}, \mathrm{~N}-\mathrm{NH}_{4}, \mathrm{SO}_{4}{ }^{2}, \mathrm{Cl}^{-}$electric conductivity (EC), and $\mathrm{pH}$. Organic matter contents were determined by using the chromic acid titration method according to Walkely and Black (1934). Total nitrogen in soil was determined by semi-micro-Kjeldahl procedure. Phosphorous was 
measured, using the Perkin-Elmer Model UVNISLambada 2 apparatus (Überlingen, Germany). Potassium, sodium, and calcium contents were measured by flame photometer. Anions and cations were measured according to Estefan et al. (2013). A Perkin-Elmer Model 1100 atomic absorption spectrometer (Perkin-Elmer, 145 Model UVNIS-Lambada 2 Uberlingen, Germany) was used for determination of soil $\mathrm{Fe}, \mathrm{Mg}$, and $\mathrm{Zn}$ content (Lindsay and Norvell 1978).

\section{Cropping succession program}

The crop succession program was designed to be as follows: corn, potato intercropped with cabbage, onion, cowpea, wheat, corn again, and finally potato. An area of $1200 \mathrm{~m}^{2}$ was designated for conducting the experiment in each district. Each field contained eight plots $(15 \times$ $10 \mathrm{~m}^{2}$ ). Incidence of the bacterial pathogen was detected before planting in each soil, irrigation water source, and volunteer plant samples, using a serial dilution agar plate method on the semi-selective medium of South Africa (SMSA) modified by Elphinstone et al. (1996).

Crop succession program was implemented as following:

1. Corn (Hybrid SC123) (June-October)

2. Susceptible certified potato seed variety, Lady Rosetta intercropped with cabbage. (Brassica oleracea L.-cabbage (American variety)) (November-February)

Potato seeds were planted in three rows about $90 \mathrm{~cm}$ between rows and about $30 \mathrm{~cm}$ space within rows. The seedlings of the cabbage intercropped with potato were planted in the same rows of potato but in the other side. Four plots were intercropped by cabbage, and another four plots were planted with potato only (without cabbage).

3. Onion, Allium cepa L. (Copra F1) (March-June)

4. Cowpea, Vigna sinensis L. (July-15 October)

5. Wheat, Triticum aestivum L. (SIDS1) (1 Mar-30 Jun)

6. Corn (Hybrid SC123) (July-October)

7. Potato (Spunta) (November-Feb)

\section{Monitoring of the pathogen in different fields}

Pooled soil, rhizosphere, and plant tissue samples were collected from each plot and were assayed for the incidence of $R$. solanacearum. The pathogen was monitored after planting each crop in soil, rhizosphere, and in plant tissues. Detection of the pathogen was made by selective media (SMSA), and suspected typical virulent colonies (irregular slimy with pink center and white margins (Elphinstone et al. 1996)) were confirmed by immunofluorescence antibody staining (IFAS) and realtime PCR (RT-PCR), randomly selected typical virulent colonies (Weller et al. 2000), followed by pathogenicity test on young tomato seedlings. Total virulent CFUs were calculated per grams of dry soil or plant tissues.

\section{Microbial community determination after each crop}

Soil and crop rhizosphere samples were collected from each plot (8 plots/area). Evaluation of microbial diversity as shown by copitrophic, oligotrophic, heterotrophic bacteria, endospores, fluorescent pseudomonas, actinomycetes, and fungi was performed for soil and rhizosphere of different crops. Standard media for each group of microorganisms were used (Termorshuizen et al. 2006). The relation of different microbial groups and disease suppression was investigated. About 50 colonies developed on each of the 7 different standard media were randomly selected for testing their antagonistic potential against $R$. solanacearum as described in Messiha et al. (2007b). The percentage of antagonists to the total microbial count was calculated for each crop soil and rhizosphere. The ability of the fluorescent antagonistic isolates to produce phenazine-1-carboxylic acid (PCA) and 2,4-diacetylphloroglucinol (Phl), using the specific primers (Table 1), was carried out according to Raaijmakers et al. (1997).

\section{Identification of biocontrol agents}

Identification of the antagonists was made by using 8capillary sequencer ABI-3500. DNA extraction of antagonistic bacteria was made by suspending one colony $(2-\mathrm{mm})$ in lysis solution, boiling for $15 \mathrm{~min}$, followed by centrifugation at $12,000 \mathrm{~g}$, and diluting the supernatant 50-fold in MQ water. Twenty nanograms of genomic DNA template was added to each $25 \mu$ PCR reaction. Antagonistic actinomycetes cultures were macerated under liquid nitrogen till complete conversion into powder; then, the DNA extraction was completed using the NucleoSpin 'Soil kits escaping the first two steps (sample lysis and adjusting lysis conditions using NucleoSpin ${ }^{\circ}$ Bead tubes). DNA sequencing was made either by amplifying the V6 to V8 region of the $16 \mathrm{~S}$ rRNA gene (Table 1), as described in Hiddink et al. (2005) or by MicroSeq ${ }^{\circ} 500$ targeting the first $500 \mathrm{bp}$ of the $17 \mathrm{~S}$ rRNA gene (using 16S rDNA microbial identification kit) provided by Applied Biosystem. DNA sequencing and identification was obtained using 8-capillary Genetic Analyzer (Applied Biosystem), provided by STDF (Science and Technology Development Fund)) at ARC, Egypt, as described in Farag et al. (2017). Bioedit software was employed and fasta DNA consensus sequence database was compared with the sequences of 
Table 1 Primers employed for identification of Eubacterial antagonistic strains and screening for the antibiotic producing ability of fluorescent pseudomonades (Raaijmakers et al. 1997)

\begin{tabular}{|c|c|c|c|}
\hline Target gene & Primer & Sequence $\left(5^{\prime}-3^{\prime}\right)$ & Amplicon size \\
\hline \multirow[t]{2}{*}{$16 \mathrm{~S}$ rDNA } & U968-f (eubacteria) & 5'ACCGCGAAGAACCTTAC3' & $450 \mathrm{bp}$ \\
\hline & L1401-r (eubacteria) & 5'-CGG TGT GTA CAA GACCC-3' & \\
\hline \multirow[t]{2}{*}{ phID ${ }^{1}$} & $\mathrm{Phl} 2 \mathrm{a}$ & GAGGACGTCGAAGACCACCA & $745 \mathrm{bp}$ \\
\hline & $\mathrm{Ph} 2 \mathrm{~b}$ & ACCGCAGCATCGTGTATGAG & \\
\hline \multirow[t]{2}{*}{$p h z C D^{2}$} & PCA2a & TTGCCAAGCCTCGCTCCAAC & $1150 \mathrm{bp}$ \\
\hline & PCA3b & CCGCGTTGTTCCTCGTTCAT & \\
\hline
\end{tabular}

${ }^{1}$ Gene responsible for producing 2,4-diacetylphloroglucinol (Phl) antibiotic

${ }^{2}$ Gene responsible for producing phenazine-1-carboxylic acid (PCA) antibiotic

the DNA Gene Bank database using the BLASTN algorithm (http://blast.ncbi.nlm.nih.gov/Blast.cgi).

\section{Statistical analysis}

Linear contrast and post hoc analysis Dunnett $t(<$ control) ${ }^{\mathrm{a}}$ for one-way independent ANOVA (SPSS 23) was employed to test the significant difference in density of the pathogen in soil and rhizosphere after different crops as compared to the inoculum density of the pathogen in soil (control) before starting the cropping system. Mann-Whitney test Asymp. Sig. (2tailed) was employed for comparing the ranks of different tested data.

\section{Results and discussions}

Crop rotation is being recommended for improvement of soil structure and organic matter, decreasing erosion, increasing microbial diversity and activity and indirectly decreases incidence of soil-borne pathogens.

\section{Physical and chemical characteristics of different soil types}

As shown in Table 2, Wardan and Ganoub Eltahrir were classified as sandy soils while Talia and Sids were classified as silt clay soils. The sandy soils were characterized by a high $\mathrm{pH}$ and a high sulfur content, low electric conductivity (EC), saturation percentage (SP), organic matter (OM), and as well as low content of potassium, iron, and calcium. Wardan had strong alkaline soil with $\mathrm{pH}$ 8.8 and poor nutrient with low SP (22\%), low OM (0.6\%), K ( $\approx 50 \mathrm{mg} / \mathrm{kg}), \mathrm{Mn}(2.9 \mathrm{ppm})$, and Fe (2.2 ppm). Meanwhile, phosphorous and sulfur soil contents were being high. Silt clay soils sampled from Talia and Sids were characterized by a low $\mathrm{pH}$ (less alkalinity), a high organic matter, and high $\mathrm{K}$ and $\mathrm{Mn}$ contents than in the sandy soils. Talia soil was characterized by a low $\mathrm{C}$ to $\mathrm{N}$ ratio $(9: 1)$ and a very low $\mathrm{N}-\mathrm{NO}_{3}(0.6 \mathrm{mg} / \mathrm{kg})$, low phosphorous $(6.6 \mathrm{mg} / \mathrm{kg})$, and sulfur $(77.9 \mathrm{ppm})$, while Fe was highest $(14.3 \mathrm{ppm})$ than all other soils. Soil from Sids area was characterized by the least alkalinity $(\mathrm{pH} 8)$, a high $\mathrm{EC}(2 \mathrm{dS} / \mathrm{m}), \mathrm{SP}$ (61\%), a $\mathrm{C}$ to $\mathrm{N}$ ratio (21), OM (2.1\%), $\quad \mathrm{N}-\mathrm{NO}_{3} \quad(226.7 \mathrm{mg} / \mathrm{kg}), \quad \mathrm{K} \quad(793.6 \mathrm{mg} / \mathrm{kg}), \quad \mathrm{Mn}$ (14.8 ppm). Anions and cations ratios were the highest, especially $\mathrm{SO}^{-2}(21.7 \mathrm{ml} / \mathrm{l}), \mathrm{Cl}^{-}(6.4 \mathrm{ml} / \mathrm{l}), \mathrm{Na}^{+}(6.2 \mathrm{ml} / \mathrm{l})$, $\mathrm{Mg}^{2+}(7.7 \mathrm{ml} / \mathrm{l})$, and $\mathrm{Ca}^{2+}(16.2 \mathrm{ml} / \mathrm{l})$.

\section{Cultural biodiversity after different crop systems}

\section{Wardan district (sandy soil)}

Considerable determinations were carried out before starting the crop succession and can be summarized as follow: the ratio of oligotrophic to copiotrophic was 9:4 in soil, the endospore ratio to total heterotrophic was $\approx$ $28 \%$, the actinomycetes was $\approx 0.2 \%$, and the total fungi and the fluorescent pseudomonads were undetectable. The dominant oligotrophic bacteria compared to copiotrophic may be attributed to the poor nutrient availability.

Planting corn was characterized mainly by decreasing the oligotrophic to copiotrophic ratio to $1: 3$ in soil only, increasing endospore ratio to $45 \%$ in soil only, actinomycetes to $\approx 16 \%$ in soil and $\approx 7 \%$ in rhizosphere, and fluorescent pseudomonads to $\approx 3.5 \%$ in both soil and rhizosphere. An actinomycetes antagonistic strain was recovered from the rhizosphere of corn at ratio of $1 \%$ (in relation to the total cultural microbial community) and showed 99\% identity to Streptomyces intermedius (Table 3, Fig. 1a and Additional file 2). This was associated by an increase in endospores, fluorescent pseudomonads, and actinomycetes. High-ratio fluorescent pseudomonad and actinomycetes were reported as indicators of soil suppressiveness (van Bruggen and Semenov 2000) (Additional file 3).

Planting potato revealed unnoticeable change in $\mathrm{mi}$ crobial groups than the previous crop, except the decrease in oligotrophic to copiotrophic to $7: 76$ ratio in potato rhizosphere and the increase in soil total fungi from $\approx 0.02 \%$ in corn soil to $0.83 \%$ in potato soil. An antagonistic fluorescent pseudomonads strain, which showed 96\% identity with Pseudomonas monteilii (Fig. $1 \mathrm{~b})$, was recovered from the potato soil at ratio of $0.6 \%$. 
Table 2 Physical and chemical soil characteristics for different soils before starting the crop succession program

\begin{tabular}{|c|c|c|c|c|c|c|}
\hline \multicolumn{3}{|l|}{ Area } & \multirow{2}{*}{$\frac{\text { Wardan }}{44.2}$} & \multirow{2}{*}{$\begin{array}{l}\text { Ganoub El-Tahrir } \\
45.0\end{array}$} & \multirow{2}{*}{$\begin{array}{l}\text { Talia } \\
6.7\end{array}$} & \multirow{2}{*}{$\frac{\text { Sids }}{6.1}$} \\
\hline Physical characteristics & Sand & Coarse & & & & \\
\hline & & Fine & 45.8 & 46.4 & 14.5 & 12.8 \\
\hline & Total & Sand & 89.9 & 91.3 & 21.2 & 18.9 \\
\hline & & Silt & 7.2 & 6.4 & 40.3 & 41.2 \\
\hline & & Clay & 2.9 & 2.4 & 38.6 & 39.6 \\
\hline \multirow[t]{19}{*}{ Chemical characteristics } & & $\mathrm{pH}$ & 8.8 & 8.5 & 8.2 & 8.0 \\
\hline & & EC & 0.9 & 0.8 & 1.3 & 2.0 \\
\hline & & SP & 22.0 & 23.0 & 54.0 & 61.0 \\
\hline & & $\mathrm{C} / \mathrm{N}$ & 11.5 & 13.5 & 9.0 & 21.7 \\
\hline & & OM & 0.6 & 0.9 & 1.8 & 2.1 \\
\hline & Available macro-elements, mg/kg & $\mathrm{N}-\mathrm{NO}_{3}$ & 14.78 & 16.45 & 0.6 & 226.73 \\
\hline & & $\mathrm{N}-\mathrm{NH}_{4}$ & 40 & 44.5 & 40 & 44.5 \\
\hline & & K & 49.8 & 63.4 & 310.4 & 793.6 \\
\hline & & $P$ & 24.3 & 10.6 & 6.6 & 8.8 \\
\hline & micro-ppm & $\mathrm{Fe}$ & 2.2 & 6.1 & 14.3 & 11.5 \\
\hline & & $\mathrm{Zn}$ & 2.1 & 2.8 & 2.8 & 1.3 \\
\hline & & S & 117.9 & 125.1 & 77.9 & 99.8 \\
\hline & Total anions (ml/l) & SO4 & 7.0 & 6.7 & 9.8 & 21.7 \\
\hline & & $\mathrm{Cl}$ & 3.2 & 3.0 & 3.9 & 6.4 \\
\hline & & $\mathrm{HCO} 3$ & 2.7 & 2.1 & 2.6 & 2.7 \\
\hline & Total cations (ml/l) & K+ & 0.5 & 0.5 & 0.3 & 0.6 \\
\hline & & $\mathrm{Na}+$ & 4.3 & 3.2 & 4.2 & 6.2 \\
\hline & & $\mathrm{Mg}++$ & 3.1 & 2.7 & 3.9 & 7.7 \\
\hline & & $\mathrm{Ca}++$ & 5.0 & 5.4 & 7.9 & 16.2 \\
\hline
\end{tabular}

Cabbage soil and rhizosphere differed than potato only in supporting less actinomycetes (about half) and less fluorescent pseudomonads (less than half) than in the potato soil and rhizosphere.

Planting onion is characterized with noticeable changes in all microbial groups than the previous crops (potato intercropped with cabbage) as follows: the ratio of oligotrophic to copiotrophic increased to $1: 2$ in soil and 4:3 in rhizosphere of onion and decreased in soil endospores, actinomycetes, and fungi in soil to $\approx 1 \%, 0.8 \%$, and $0.03 \%$, respectively, in relation to total microbial count. A noticeable increase in fluorescent pseudomonads to $\approx 5 \%$ and $10 \%$ in soil and rhizosphere, respectively, was recorded. An antagonistic strain showing 99\% identity with Leclercia adecarboxylata (Table 3) was recovered from the onion soil at a ratio of $0.7 \%$. Antagonistic strains showing 99\% identity with Pseudomonas putida group (Table 3) were recovered from onion soil at a ratio of $2.1 \%$ in relation to the total microbial community; most of them were producing phenazine-1-carboxylic acid (PCA). A strong antagonistic strain showing $100 \%$ identity with Pseudomonas panacis/Pseudomonas brenneri (Pseudomonas fluorescens group) (Fig. 1) was recovered from onion soil at a ratio of $0.7 \%$. Antagonistic strains showing 99\% with $P$. putida group were recovered from onion rhizosphere at a ratio of $5 \%$ in relation to the total microbial community and were able to produce phenazine-1carboxylic acid (PCA). Antagonistic isolates showing 99\% identity with Pseudomonas fulva and recovered from onion rhizosphere at a ratio of 5\%. Antagonistic strains showing 99\% identity with Stenotrophomonas maltophilia/Stenotrophomonas pavanii/Stenotrophomonas chelatiphaga, Stenotrophomonas humi and Pseudomonas geniculate were recovered from rhizosphere of onion at a ratio of $0.6 \%$ (Table 3 ).

Planting cowpea resulted in a noticeable increase in the ratio of oligotrophic to copiotrophic, reached 16:9 in soil and decreased to 1:5 in cowpea rhizosphere in relation to heterotrophic bacteria. This trend was reversed in wheat rhizosphere, where the ratio between oligotrophic and copiotrophic increased to 2:1 and the ratio of endospores sharply decreased (10\%), similarly in both soil and rhizosphere, while fluorescent pseudomonads increased (11\%), especially in wheat rhizosphere. An antagonistic actinomycetes strain (Table 3) showed $99 \%$ of S. erythrogriseus group at a 
Table 3 List of the bacterial antagonists recovered from soil and rhizosphere of different crops

\begin{tabular}{|c|c|c|c|c|c|c|c|c|}
\hline & Wardan & $c$ & Ganoub El-Tahrir & 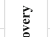 & Talia & 党 & Sids & tiv \\
\hline Crop & & 这 & & 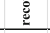 & & 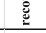 & & 莣 \\
\hline \multirow[t]{3}{*}{ Corn } & Streptomyces intermedius $(99 \%)$ & $1.0 \%$ & & & & & Streptomyces erythrogriseus (99\%) & $1.0 \%$ \\
\hline & & & & & & & Streptomyces coeruleorubidus group $(99 \%)$ & $1.0 \%$ \\
\hline & & & & & & & Streptomyces spp $(100 \%)$ & $1.0 \%$ \\
\hline \multirow[t]{4}{*}{ Potato/cabbage } & Pseudomonas monteilii $(96 \%)$ & $0.6 \% s$ & Streptomyces albidoflavus group / & $0.8 \%$ & Stenotrophomonas maltophilia & $1.0 \%$ & ${ }_{6}$ Bacillus marcorestinctum $(98 \%)$ & $2.0 \%$ \\
\hline & & & Streptomyces argenteolus group (99\%) & & Citrobacter murliniae/ C. braakii (99\%) & $1.0 \%$ & 6 Serratia quinivorans $(99 \%)$ & $2.0 \%$ \\
\hline & & & Pseudomonas putida group $(99 \%)^{1}$ & $0.7 \%$ & 6 Serratia quinivorans/S. proteamaculans $(99 \%)$ & $2.0 \%$ & P. putida group $(99 \%)^{1}$ & $0.2 \%$ \\
\hline & & & & & Pseudomonas protegens $(92 \%)^{1}$ & $3.0 \%$ & & \\
\hline \multirow[t]{5}{*}{ Cabbage } & & & Streptomyces caeruleatus $(99 \%)$ & $1.4 \%$ & Pseudomonas sp $(98 \%)^{1}$ & $1.0 \%$ & Bacillus cereus/B. thuringiensis (99\%) & $1.0 \%$ \\
\hline & & & & & Pseudomonas rhizosphaerae $(97 \%)$ & $1.0 \%$ & - Pseudomonas brassicacearum/P. corrugate $(99 \%)^{1}$ & $1.0 \%$ \\
\hline & & & & & Pseudomonas vranovensis (98\%) & $1.0 \%$ & P. vranovensis/ P. reidholzensis $(99 \%)$ & $1.0 \%$ \\
\hline & & & & & S. proteamaculans $(86 \%)$ & $1.0 \%$ & P. putida group $(99 \%)$ & $1.0 \%$ \\
\hline & & & & & Perlucidibaca aquatic $(82 \%)$ & $1.0 \%$ & & \\
\hline \multirow[t]{6}{*}{ Onion } & Leclercia adecarboxylata $(99 \%)$ & $0.7 \% \mathrm{I}$ & P. putida group $(99 \%)^{1,2}$ & $8.2 \%$ & P. mendocina/ $P$. aeruginosa strain/ & $0.4 \%$ & P. mendocina $(97 \%)^{1}$ & $3.0 \%$ \\
\hline & P. putida group $(99 \%)^{\mathrm{t}}$ & $7.1 \% s$ & S. maltophilia/S. pavanii/ P. chelatiphaga/ & & P. guguanensis $(99 \%)$ & & S. maltophilia & $1.0 \%$ \\
\hline & Pseudomonas brenneri/panacis $(100 \%)$ & $0.7 \%$ & P. humi/P. geniculate $(97 \%)$ & $3.2 \%$ & & & Pseudomonas plecoglossicida $(99 \%)$ & $1.0 \%$ \\
\hline & Pseudomonas fulva $(99 \%)$ & $5.0 \% t$ & Bacillus spp & $1.2 \%$ & & & P. putida group $(99 \%) I$ & $1.0 \%$ \\
\hline & Stenotrophomonas maltophilia/S. pavanii/ & $0.6 \% 1$ & P. entomophila/ P. monteilii $(99 \%)^{1}$ & $2.4 \%$ & & & B. cereus/ B. thuringiensis $(99 \%)$ & $1.0 \%$ \\
\hline & Pseudomonas chelatiphaga/P. humi/ $P$. gen & iculate & $(99 \%)$ & & & & Ochrobactrum rhizosphaerae $(97 \%)$ & $1.0 \%$ \\
\hline \multirow[t]{4}{*}{ Cowpea } & & & & & Pseudomonas moorei (99\%) & $2.0 \%$ & & \\
\hline & & & & & S. maltophilia (group) $(99 \%)$ & $4.0 \%$ & & \\
\hline & & & & & P. mendocina/P. aeruginosa strain/ & & & \\
\hline & & & & & P. guguanensis $(99 \%)$ & $4.0 \%$ & & \\
\hline \multirow[t]{2}{*}{ Wheat } & S. erythrogriseus group $(99 \%)$ & $1.0 \% s$ & S. maltophilia $(99 \%)$ & $1.0 \%$ & & $1.0 \%$ & & \\
\hline & & & Delftia tsuruhatensis/D, lacustris (99\%) & $1.0 \%$ & & $1.0 \%$ & & \\
\hline \multirow[t]{6}{*}{ Second corn } & Pseudomonas putida group $(98 \%)^{1}$ & $1.0 \%$ & Beijerinckia fluminensis $(95 \%)$ & $1.0 \%$ & 6 Enterobacter asburiae $(99 \%)$ & $1.0 \%$ & ${ }_{0}$ Pseudomonas fluorescens group ( $\left.93 \%\right)$ & $0.3 \%$ \\
\hline & & & P. fluorescens group (93\%) & $1.0 \%$ & ${ }_{6}^{6}$ Providencia sneebia $(99 \%)$ & $1.0 \%$ & & \\
\hline & & & Burkholderia territorii (98\%) & $1.0 \%$ & 6 S. maltophilia (group) $(99 \%)$ & $1.0 \%$ & & \\
\hline & & & S. maltophilia/S. pavanii/ P. chelatiphaga/ & & & & & \\
\hline & & & P. humi/P. geniculate $(99 \%)$ & $1.0 \%$ & & & & \\
\hline & & & P. prosekii $(99 \%)$ & $1.0 \%$ & & & & \\
\hline \multirow[t]{10}{*}{ Final Potato } & & & P. putida group $(99 \%)$ & $2.0 \%$ & ${ }_{6}^{6}$ Pseudomonas seleniipraecipitans $(98 \%)$ & $1.0 \%$ & & \\
\hline & & & S. maltophilia/S. pavanii/ P. chelatiphaga/ & $1.0 \%$ & ${ }_{0}^{6}$ P. putida $(99 \%)$ & $1.0 \%$ & & \\
\hline & & & P. humi/P. geniculate $(97 \%)$ & & S. maltophilia (gropup) $(99 \%)$ & $3.0 \%$ & & \\
\hline & & & Pseudomonas aeruginosa $(99 \%)$ & $2.0 \%$ & ${ }_{6}^{0}$ P. rhizosphaerae $(99 \%)$ & $1.0 \%$ & & \\
\hline & & & & & Citrobacter freundii $(97 \%)$ & $1.0 \%$ & & \\
\hline & & & & & Acinetobacter sp $(99 \%)$ & $1.0 \%$ & & \\
\hline & & & & & D. tsuruhatensis $(99 \%)$ & $1.0 \%$ & & \\
\hline & & & & & Serratia marcescens $(99 \%)$ & $1.0 \%$ & & \\
\hline & & & & & P. mendocina/P. aeruginosa strain/ & & & \\
\hline & & & & & P. guguanensis $(99 \%)$ & $1.0 \%$ & & \\
\hline
\end{tabular}

Identification was made by DNA sequencing either for the V6 to V8 region of the 16S rRNA gene as described in Hiddink et al. (2005) or by MicroSeq ${ }^{\oplus} 000$ (16S rDNA microbial identification kit) provided by Applied Biosystem using 8-capillary Genetic Analyzer (Applied Biosystem)

${ }^{1}$ Produce 2,4-diacetylphloroglucinol (Phl) antibiotic

${ }^{2}$ Produce phenazine-1-carboxylic acid (PCA) antibiotic (Raaijmakers et al. 1997)

ratio of $0.5 \%$ in relation to total estimated microbial community.

Planting second-year corn supported community similar to the first-year corn, and an antagonistic fluorescent bacteria showing $98 \%$ identity with $P$. putida group (Table 3) were recovered from corn rhizosphere at a ratio of $1 \%$.

\section{Ganoub Eltahrir district}

The analysis of cultural microbial diversity before starting the crop succession can be summarized as follows: the ratio of oligotrophic to copiotrophic was 5:8 in soil, the endospore ratio to total heterotrophic was $\approx 21 \%$, and the actinomycetes was $\approx 17 \%$. High percentage of fluorescent pseudomonads (about 12\% to the total microbial community) was determined before corn.

Planting corn was characterized mainly by increasing the oligotrophic to copiotrophic ratio to $19: 7$ and $24: 7$ for soil and rhizosphere, respectively. Both actinomycetes and fluorescent pseudomonads sharply declined to less than $1 \%$ in corn soil and rhizosphere.

Planting potato intercropped with cabbage decreased the oligotrophic to copiotrophic ratio to $\approx 3: 8$ in both soil and rhizosphere for the two crops. Actinomycetes and fungi ratios were increased in cabbage soil to 4 and $0.17 \%$, respectively. Dominating endospores in relation to heterotrophic bacteria were recorded; cabbage and potato soils $(\approx 50 \%)$ with lower ratio in potato and cabbage rhizosphere were 13 and $9 \%$, respectively. An antagonistic actinomycetes showing 99\% with S. albidoflavus group or $S$. argenteolus group was recovered at the ratio of $0.76 \%$ from potato soil (Table 3 ). An antagonistic isolate showing $99 \%$ identity with $P$. putida group producing PCA was recovered from potato rhizosphere at the rate of $0.7 \%$. An antagonistic isolate showing a 99\% identity with Streptomyces caeruleatus was recovered from cabbage soil at a rate of $1.4 \%$.

Planting onion was characterized with a sharp increase in oligotrophic to copiotrophic ratio in soil into 4:1. On the other hand, the heterotrophic bacteria were dominating (more than 97\%) in both soil and onion rhizosphere with reasonable percentage of fluorescent pseudomonas (15.5\% in soil and $6 \%$ in rhizosphere). Meanwhile, there was a noticeable decrease in actinomycetes and fungi in both soil and rhizosphere. Onion supported high ratio of antagonistic bacteria in soil $(\approx 7 \%$ to 


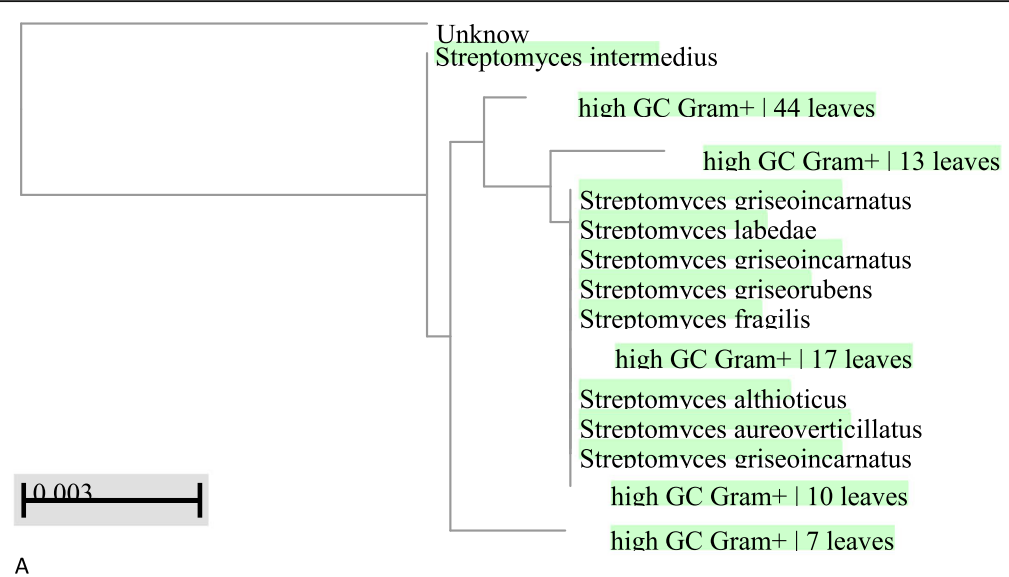

A

Unknown

Pseudomonas monteilii

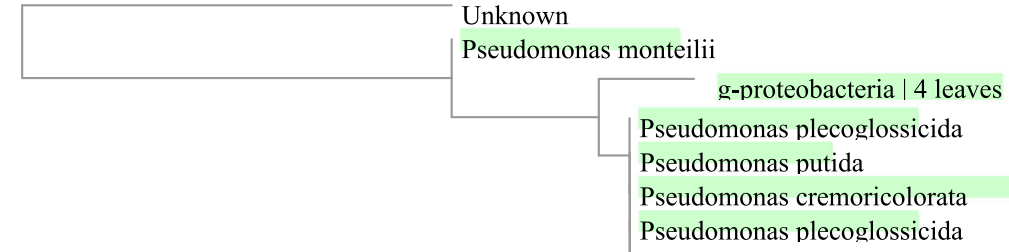

g-proteobacteria $\mid 80$ leaves

Pseudomonas guariconensis

Pseudomonas alkylphenolica g-proteobacteria $\mid 4$ leaves

Pseudomonas donghuensis

Pseudomonas parafulva

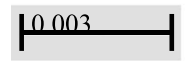

B g-proteobacteria $\mid 2$ leaves

Pseudomonas wadenswilerensis

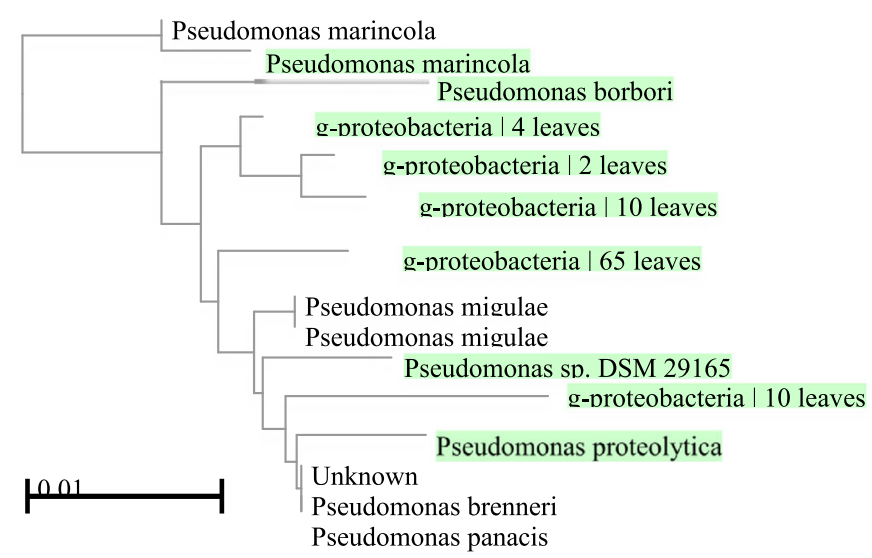

Fig. 1 a An actinomycetes antagonist recovered from corn rhizosphere at a rate of 1\% relative to total culturable microbial community (99\% identical with to Streptomyces intermedius). $\mathbf{b}$ A bacterial antagonist recovered from potato soil intercropped with cabbage at rate of $0.6 \%$ relative to total culturable microbial community ( $96 \%$ identical with to Pseudomonas monteilii). c A bacterial antagonist recovered from Onion soil at rate of $0.7 \%$ relative to total culturable microbial community ( $100 \%$ identical with $P$. fluorescens group)

total cultural bacterial community); $4.6 \%$ showed $99 \%$ identity with $P$. putida group producing both PCA and 2, 4-diacetylphloroglucinol PCA only, and $1.5 \%$ was unable to produce any of them. Another antagonistic strain showed $97 \%$ of identity with S. maltophilia and represented $0.8 \%$ of the total cultural biodiversity. Rhizosphere of onion supported high ratio of antagonistic bacteria ( $\approx 9.5 \%$ to total cultural bacterial community); $3.5 \%$ showed 99\% identity with P. putida group and was able to produce both PCA and 2,4 DAPG. Antagonistic 
Bacillus sp. represented $1.2 \%$ of the total cultural biodiversity of onion rhizosphere. Also, antagonistic strains showing 99\% with Stenotrophomonas maltophilia/ S. pavanii/ P. chelatiphaga/P. humi/P. geniculate were recovered at a rate of $2.4 \%$ of the total cultural biodiversity (Table 3). Antagonistic strains showing 99\% identity with Pseudomonas entomophila/P. monteilii (able to produce PCA) and $99 \%$ with P. entomophila/P. soli/Pseudomonas mosselii were recovered at the rate of $1.2 \%$ for each.

Planting cowpea increased endospore ratio to $38 \%$ in soil and $14 \%$ in rhizosphere, while the actinomycetes was undetectable.

Planting wheat decreased the oligotrophic to copiotrophic ratio to 1:9 and 2:3 for soil and rhizosphere, respectively. An antagonistic strain showing $99 \%$ with $S$. maltophilia/S. pavanii/P. chelatiphaga/ P. humi/ P. geniculate was recovered at a rate of $1 \%$ of the total cultural soil community (Table 3). An antagonistic strain showing 99\% identity with Delftia tsuruhatensis/Delftia lacustris was recovered at a rate of $1 \%$ of the total cultural rhizosphere community.

Planting second-year corn increased oligotrophic to copiotrophic ratio to $1: 1$ in soil and decreased the ratio to 1:3 in corn rhizosphere. There was a noticeable increase in endospore ratio into 45.7 and $25.9 \%$ in soil and rhizosphere, respectively. An antagonistic strain exhibited identity with Beijerinckia fluminensis (95\% identity), Burkholderia territorii (98\% identity), P. fluorescens group (93\% identity), Pseudomonas prosekii (99\% identity), S. maltophilia/S. pavanii/ P. chelatiphaga/P. humi/P. geniculate (99\% identity) were recovered at a rate of $1 \%$ each to total cultural rhizosphere biodiversity (Table 3).

Ending potato increased oligotrophic to copiotrophic ratio (oligotrophization) to $12: 5$ and $11: 3$ as compared with the first potato soil and rhizosphere with decreased endospores ratio, in soil only. The potato rhizosphere supported a high ratio of antagonistic community including P. putida group, S. maltophilia/S. pavanii/P. chelatiphaga/P. humi/P. geniculate and others similar to Pseudomonas aeruginosa (2\%) (Table 3).

\section{Talia district}

The analysis of cultural microbial diversity before starting the crop succession including the determination of the oligotrophic to copiotrophic ratio (8:7) in soil, the endospore ratio to total heterotrophic $(\approx 40 \%)$, actinomycetes $(\approx 21 \%)$, fungi $(0.38 \%)$, and low percentage of fluorescent pseudomonads $(0.25 \%$ from the total microbial community) was determined before corn, small shift in soil biodiversity before and after corn.

Corn rhizosphere decreased the ratio of oligotrophic to copiotrophic to $3: 8$, the endospore ratio to total heterotrophic decreased to $26 \%$, and tendency of increase in fluorescent pseudomonads to $0.6 \%$.

Planting potato intercropped with cabbage increased the oligotrophic to copiotrophic ratio to 8:9 in both soil and rhizosphere for the two involved crops. Actinomycetes ratio increased in potato/cabbage soil to $45 \%$. Dominating endospores in relation to heterotrophic bacteria were recorded for cabbage rhizosphere $(\approx 99 \%)$ with a lower ratio in potato rhizosphere being 13. Antagonistic strains yielding 98\% of Pseudomonas sp. (producing PCA), 97\% of Pseudomonas rhizosphaerae, 98\% of Pseudomonas reidholzensis/Pseudomonas vranovensis, $86 \%$ of Serratia proteamaculans, and $82 \%$ of Perlucidibaca aquatic were recovered at the rate of $1 \%$ for each of the total cultural biodiversity in cabbage rhizosphere. Antagonistic strains which showed 99\% with S. maltophilial[Pseudomonas] geniculate/S. humi/Stenotrophomonas acidaminiphila, 99\% with Citrobacter murliniael Citrobacter braakii, 99\% with Serratia quinivorans/S. proteamaculans, and $92 \%$ with Pseudomonas protegens (producing PCA) were recovered at a rate of 1, 1, 2, and $3 \%$, respectively, of total cultural biodiversity of potato rhizosphere (Table 3).

Planting onion increased oligotrophic to copiotrophic ratio in rhizosphere only to 5:6 with an increase in endospore ratio to heterotrophic to 31 and $15 \%$ in both soil and onion rhizosphere, respectively. Rhizosphere of onion supported $\approx 0.4 \%$ ratio of Pseudomonas mendocina/P. aeruginosa strain/Pseudomonas guguanensis to total culturable bacterial community.

Planting cowpea decreased oligotrophic to copiotrophic to 1:2. Meanwhile cowpea rhizosphere supported by a high ratio of antagonists; $2 \%$ showed $99 \%$ identity to Pseudomonas moorei, along with $99 \%$ identity to $S$. maltophilia/S. pavanii/P. chelatiphaga/P. humi/P. geniculate and $4 \%$ showed $99 \%$ identity with $P$. mendocinal $P$. aeruginosa strain/P. guguanensis (99\%).

Planting wheat decreased the oligotrophic to copiotrophic ratio to a neglected level in rhizosphere and decreased endospore ratio to 5 and $2 \%$ in soil and rhizosphere, respectively.

Planting second-year corn increased endospore ratio to 18 and 5\% in soil and rhizosphere, respectively. Planting second-year corn supported reasonable percentage of antagonistic bacteria (3\%) in relation to total cultural microbial community. The antagonistic strains showed 99\% identity with Pseudomonas moorei, along with Providencia sneebia and S. maltophilia/S. pavanii/P. chelatiphaga/P. humi/P. geniculate.

Ending potato increased oligotrophic to copiotrophic ratio (oligotrophization) to $21: 8$ and $1: 1$ than in the firstyear crop in potato soil and rhizosphere, respectively, and increased endospores ratio, in soil only, up to $83 \%$ of total cultural biodiversity. The potato soil and 
rhizosphere supported a high ratio of antagonistic strains with 98\% identity with Pseudomonas seleniipraecipitans, and P. putida, S. pavanii/S. maltophilial[Pseudomonas] geniculate/S. humi/S. acidaminiphila, along with $99 \%$ identity with [Pseudomonas] geniculate/Pseudomonas hibiscicola, P. rhizosphaera and $97 \%$ identity with Citrobacter freundii. Potato rhizosphere supported high ratio of antagonistic strains (8\%), 1 with 99\% identity with Acinetobacter sp., 2 showed 99\% identity with S. pavanii/S. maltophilial[Pseudomonas] geniculate/S. humi/S. acidaminiphila, 1 with $99 \%$ identity with $D$. tsuruhatensis/D. lacustris, $2 \%$ identity with Serratia marcescens, and $2 \%$ with $P$. mendocina /P. guguanensis/P. aeruginosa (Table 3).

\section{Sids district}

The analysis of cultural microbial diversity before starting experimentation revealed that the percentage of the endospore to the total heterotrophic was $\approx 52 \%$, and the actinomycetes was $\approx 6 \%$, along with a low percentage of fluorescent pseudomonads (about $0.05 \%$ from the total microbial community) recorded before corn.

Planting corn was resulted in a balanced oligotrophic to copiotrophic ratio being 5:7 and 1:1 for soil and rhizosphere, respectively, and the endospore was 18 and $30 \%$ in soil and rhizosphere, respectively, with a little tendency of increased fluorescent pseudomonads to 0.8 and $0.3 \%$ in corn soil and rhizosphere, respectively. Corn rhizosphere supported a high ratio of antagonistic actinomycetes strains $(\approx 3 \%)$; the strains showed $99 \%$ identity with Streptomyces matensis/Streptomyces erythrogriseus/Streptomyces aureoverticillatus/Streptomyces griseoincarnatus/Streptomyces variabilis, 99\% identity with Streptomyces coeruleorubidus group, and 100\% identity with Streptomyces spp.

Planting potato intercropped with cabbage increased the copiotrophic ratio to $93 \%$ in both soil and rhizosphere of cabbage than those of potato ratio showing $80 \%$ in potato rhizosphere. Actinomycetes ratio increased in potato/cabbage soil and rhizosphere to $\approx 11 \%$. The ratio endospores in relation to heterotrophic bacteria recorded 34, 64, and $24 \%$ for soil and those of cabbage and potato rhizosphere. Antagonistic strains which showed $98 \%$ identity with Bacillus marcorestinctum and 99\% with Serratia quinivorans were recovered at a rate of $2 \%$ for potato/cabbage soil. An antagonistic strain showing 99\% identity with Pseudomonas putida group was recovered from the potato rhizosphere at a rate of $0.2 \%$. The rhizosphere of cabbage supported $4 \%$ of antagonistic strains in relation to a total bacterial biodiversity and was identified as one strain showing 99\% identity with Bacillus cereus/Bacillus proteolyticus/Bacillus thuringiensis/Bacillus toyonensis/Bacillus wiedmannii/Bacillus paranthracis/Bacillus mobilis/Bacillus
pacificus/Bacillus marcorestinctum. Others showed 99\% identity with Pseudomonas abietaniphila/Pseudomonas brassicacearum/P. corrugate/Pseudomonas migulae, with Pseudomonas vranovensis/P. reidholzensis and 99\% similarity with Pseudomonas putida group.

Planting onion decreased endospore ratio to 10 and $3 \%$, actinomycetes to 1 and $0.1 \%$ in soil and rhizosphere, respectively. Onion soil supported a high ratio of antagonists (10\%), representing 3.5\% fluorescent pseudomonads (showing 97\% identity with Pseudomonas mendocina, 99\% identity with Pseudomonas plecoglossicida, $99 \%$ with $P$. putida group, and $99 \%$ with $P$. aeruginosa/P. mendocina/P. guguanensis). The rest of the recovered antagonists were identified as $S$. maltophilia strain SA21-01, Pseudomonas hibiscicola/Stenotrophomonas pavanii, Bacillus cereus/B. thuringiensis/Streptococcus agalactiae, and Ochrobactrum rhizosphaerae. The onion rhizosphere supported reasonable ratio of antagonistic fluorescent pseudomonads (1.5\%) and was identified as Pseudomonas aeruginosa/P. mendocina/P. guguanensis.

Planting cowpea sharply declined the ratio of oligotrophic to copiotrophic to 1:20 and 1: 40 in soil and rhizosphere, respectively, along with a decrease in fluorescent pseudomonads ratio and a noticeable increase in endospore ratio to 37 and $19 \%$ in soil and rhizosphere, respectively.

Planting wheat increased fluorescent pseudomonads ratio to $\approx 2 \%$ than the total cultural microbial community in both soil and rhizosphere.

The rhizosphere of second-year corn supported $0.3 \%$ of an antagonistic strain, showing $93 \%$ identity to $P$. fluorescens group (Table 3).

Ending potato is characterized by a dominant copiotrophic over the oligotrophic (2:25 and 3:20 for soil and rhizosphere, respectively) and dominant heterotrophic than endospores (93 and 99\% for soil and rhizosphere, respectively). The ratio of actinomycetes, fungi, and fluorescent pseudomonads was neglected in both potato soil and rhizosphere.

\section{Pathogen density in different habitats before and after planting of different crops}

The density of the pathogen in soil and in the congenial plant species (weeds) was evaluated in each field prior to starting the crop succession program (Table 4). The density of the pathogen in soil and rhizosphere after different crops revealed that it was undetectable in both sandy and clay soils and rhizosphere of first-year corn, onion, wheat, second-year corn, and ending potato. However, an increase in pathogen density was detected in potato intercropped with cabbage along with cowpea in both soil and rhizosphere. Moreover, a significant decrease of pathogen density in the soil after harvesting 
Table 4 Densities of Ralstonia solanacearum in soil and in plant tissues of congenial plant species prior starting the crop succession program

\begin{tabular}{|c|c|c|}
\hline Area & & $\begin{array}{l}\log (C F U+1) / \\
g(\text { mean } \pm \text { SE) }\end{array}$ \\
\hline \multirow[t]{5}{*}{ Wardan (sandy soil) } & Soil & $0.82 \pm 0.41$ \\
\hline & Congenial plant species & \\
\hline & Chenopodia palvilora (1 plant) & 0.00 \\
\hline & Cynodum dactylum (1 plant) & 1.61 \\
\hline & Malva spp. (1 plant) & 2.00 \\
\hline \multirow{6}{*}{$\begin{array}{l}\text { Ganoub El-Tahrir } \\
\text { (sandy soil) }\end{array}$} & Soil & $3.79 \pm 0.18$ \\
\hline & Congenial plant species & \\
\hline & Arachis hypogaea (6 plants) & $3.26 \pm 0.51$ \\
\hline & Lolium perenne (7 plants) & $3.91 \pm 0.48$ \\
\hline & Solanum nigrum (1 plant) & 3.34 \\
\hline & $\begin{array}{l}\text { Solanum tuberosum (3 left } \\
\text { over potatoes) }\end{array}$ & $4.19 \pm 0.37$ \\
\hline \multirow[t]{11}{*}{ Talia (clay soil) } & Soil & $3.13 \pm 0.51$ \\
\hline & Congenial plant species & \\
\hline & Amaranthus sylvestris (1 plant) & 0.00 \\
\hline & Chenopodium spp. (1 plant) & 0.00 \\
\hline & Cichorium palmilum (1 plant) & 2.00 \\
\hline & Corchorus olitorius (1 plant) & 1.61 \\
\hline & Cyperus difformis L. (3 plants) & $0.77 \pm 0.77$ \\
\hline & Dinebra retroflexa (3 plants) & $2.3 \pm 0.3$ \\
\hline & Portulaca oleracae (1 plant) & 3.00 \\
\hline & $\begin{array}{l}\text { Solanum tuberosum (10 left } \\
\text { over potatoes) }\end{array}$ & $2.24 \pm 0.52$ \\
\hline & Stellaria media (1 plant) & 0.00 \\
\hline \multirow[t]{4}{*}{ Sids (clay soil) } & Soil & $2.74 \pm 0.21$ \\
\hline & Congenial plant species & \\
\hline & Portulaca oleracae (8 plant) & $0.00 \pm 0.00$ \\
\hline & Zea mays (3 plants) & $0.00 \pm 0.00$ \\
\hline
\end{tabular}

The italics are for the scientific names of the weeds

first-year corn was recorded in sandy soils but not in clay ones. The recorded decrease in pathogen density in sandy soil at Ganoub Eltahrir was $87 \%$ decrease as it was severely infested area to undetectable level in the mild infested area at Wardan. Non-significant change in the pathogen density was detected before and after corn for the clay soils.

Conclusive remarks: considerable experimentation remarks on sandy and clay soil are summarized in the following:

\section{Sandy soils}

(a) Wardan district The density of the pathogen in soil before crop succession experimentation was (0.82 \pm 0.41) $\log _{10}(\mathrm{CFU} / \mathrm{g})+1$ (mean $\left.\pm \mathrm{SE}\right)$. The low density of $R$. solanacearum may be attributed directly or indirectly to the soil chemical characteristics. A negative correlation between $\mathrm{pH}$ and disease severity was previously recorded (Messiha et al. 2007a) and is being noted in the present study. The inter-relation between poor nutrients and the high inoculum density of the pathogen was discussed and explained by Löbmann et al. (2016). Moreover, the high ratio of sulfur and phosphorus may explain the low pathogen density as shown in the present work. Phosphorous and sulfur had an inhibitory effect against $R$. solanacearum (Williams and Cooper 2004; Norman et al. 2006).

The pathogen was detected in two congenial plant species namely, Cynodon dactylon and Malva spp., 1.61 and $2.00 \mathrm{CFU} / \mathrm{g}$ (plant tissues), respectively. The density of the pathogen in the soil and rhizosphere, for different planted crops, was compared with those of the pathogen in soil before starting succession program and the results were compared. The pathogen showed a trend of significant decrease to an undetectable level in soil after corn $(P=0.06)$. The pathogen showed a significant increase after planting potato intercropped with cabbage into 3.8 \pm 0.06 and $3.5 \pm 0.04$ in cabbage and potato soils $(P=$ 0.001 ), respectively (Fig. 2). The pathogen was undetectable in cabbage rhizosphere $(P<0.001)$ and in potato rhizosphere $(3.5 \pm 0.5)$, which was insignificantly different than that in soil before starting the experiment. Meanwhile, a decrease in disease incidence, as expressed by decrease in wilt severity from 31 to $11 \%(P \leq 0.01)$, was recorded for potato plants intercropped with cabbage as compared with potato grown solely treatment. This emphasizes the suppressing effect of cabbage roots on $R$. solanacearum. The potato soil was characterized by a reasonable ratio of fluorescent pseudomonads and supported a little ratio of antagonistic strain resembling P. monteilii. The antimicrobial activity of the cabbage roots was attributed to isothiocyanates production, which was similar to the chemical group produced upon decomposition of metham sodium as addressed by Akiew and Trevorrow (1999).

The pathogen was undetectable after onion $(P=0.06)$, and density increased again, thereafter, planting cowpea to $1.6 \pm 0.5$ and $2.6 \pm 0.7$ for soil and rhizosphere, respectively. Onion soil and rhizosphere supported the highest ratio of antagonists than the other crops with increasing oligotrophic bacteria (oligotrophism) and dominant fluorescent pseudomonads ( $P$. putida and $P$. fluorescens groups) producing PCA with a low ratio of Leclercia adecarboxylata resembling strain and S. maltophilia. Oligotrophism as a result of succession and dominance fluorescent pseudomonas are indicators of soil health and disease suppression as postulated by van Bruggen and Semenov (2000). Meanwhile, rhizosphereinhabiting fluorescent Pseudomonas spp. had critically 
produced compounds inhibitive to soil borne plant pathogens (Funnell-Harris et al. 2013). Onion and garlic were suggested for different crop rotations of brown rot control as postulated by Reddy (2017). The pathogen was detectable again in cowpea soil with even a higher ratio in cowpea rhizosphere than its soil. This was attributed to a decrease in oligotrophic ratio in cowpea rhizosphere along with a noticeable increase in endospore ratio to be dominant in cowpea rhizosphere as well as a decreased fluorescent pseudomonas ratio. No antagonists were detected either in cowpea soil or rhizosphere. These conditions may explain the enhancement of soil conduciveness conditions for the pathogen after planting cowpea. The pathogen was undetectable in wheat soil and rhizosphere. This decline in pathogen persistence was accompanied by a sharp decline in endospores along with a significant increase in fluorescent pseudomonads, along with a considerable increase of antagonistic Streptomyces spp.

The pathogen was undetectable in soil and rhizosphere of wheat and second-year corn $(P<0.001)$. The suppressive effect of soil and rhizosphere of wheat may be attributed to the long life span (6 months) as well as the fluorescent pseudomonad density and the antagonistic Streptomyces spp. ratio. Potato which is planted at the end of the crop succession program was found free of the pathogen in soil, rhizosphere, plant tissues, and potato tubers. This soil suppressing was accompanied by an increase in endospore, fluorescent pseudomonads, and actinomycetes ratios compared to densities at the experimentation onset (Fig. 2).

(b) Ganoub Eltahrir district The density of the pathogen in soil before starting the crop succession was $(3.79 \pm$ 0.18) $\left(\log _{10}+1\right) \mathrm{CFU} / \mathrm{g}$ soil. The pathogen was detected in many other congenial plant species namely 6 Arachis hypogaea plants $(3.26 \pm 0.51) \mathrm{CFU} / \mathrm{g}, 7$ Lolium perenne plants $(3.91 \pm 0.48) \mathrm{CFU} / \mathrm{g}, 1$ Solanum nigrum plant 3.34 $\mathrm{CFU} / \mathrm{g}$, and 3 left over potato tubers (Solanum tuberosum) $(4.19 \pm 0.37) \mathrm{CFU} / \mathrm{g}$ fresh plant. A. hypogaea and $S$. nigrum were previously recorded as alternative hosts by Chen et al. (2014), while L. perenne was possibly not previously recorded. The soil $\mathrm{pH}$ was lower in this district than in the Wardan area; the negative correlation between $\mathrm{pH}$ and survival of the pathogen was previously addressed by Messiha et al. (2009). Although the soil supported a high ratio of fluorescent pseudomonads and actinomycetes on the start of the experiment, the leftover infected potato and the infected congenial plant species contrary had released these high densities that render the treatment not effective. Meanwhile, a high content of iron in soil suppresses siderophore production minimizing the potential of some fluorescent pseudomonads. Ninety percent decrease in density of the pathogen in corn soil $(1.49 \pm 0.58)$ and rhizosphere $(1.58 \pm 0.6)$ were recorded $(P=0.004)$. Meanwhile, planting corn decreased the copiotrophic bacteria, actinomycetes, and fluorescent pseudomonades, which may be attributed to the high secretion of hydrocyanic acid that coincided with vigorous plant growth at this area compared to Wardan sand area. This vigorous growth may be due to certain edaphic factors such as the ratio of growth-promoting organisms such as fluorescent pseudomonads and actinomycetes. The production of hydrocyanic acid $(\mathrm{HCN})$ in corn rhizosphere was proven earlier toxic to microorganisms in soil (Francis and Connell 1913). $\mathrm{HCN}$ is toxic to most organisms (Osbourn 1996), which may explain the decrease in copiotrophic, actinomycetes, and fluorescent pseudomonades after planting corn in this area. Such sharp decrease may explain the extended survival of the pathogen in soil after planting corn.

The density of the pathogen was $3.44 \pm 0.06$ in potato soil which is not significantly different than the beginning of the experiment and was $3.2 \pm 0.13$ in cabbage soil $(15.6 \%$ decrease $)(P=0.001)$ at the beginning of the experiment. The density of the pathogen in rhizosphere of potato intercropped with cabbage was $2.74 \pm 0.42$ and was not detected in the rhizosphere of cabbage $(P<$ 0.001) (Fig. 2). Planting potato intercropped with cabbage increased the ratio of actinomycetes in general and antagonistic Streptomyces spp. in particular such as groups of S. albidoflavus, S. argenteolus, and S. caeruleatus as well as PCA antibiotic produced by P. putida. Moreover, S. albidoflavus was recorded as a biofungicide and growth-promoting substances (Haggag et al. 2014). $S$. argenteolus was $\mathrm{N}$-acylhomoserine lactones (AHLs) degrading isolates (Park et al. 2005) that inactivate or inhibit the pathogenesis of the plant pathogens (Wang et al. 2012). Pseudomonas spp. have the ability to produce an array of effective molecules that limits other soil and rhizosphere microorganisms, and produce siderophores as pyoverdine and pyochelin, which are strong chelator for iron. Another biocontrol mechanism depends on antibiotics production including phenazines, such as PCA (Raaijmakers et al. 2010). Pseudomonas bacteria can mediate different types of bacteriocins and toxins (Waite and Curtis 2009).

$R$. solanacearum were undetectable in both soil and rhizosphere after onion $(P<0.001)$. It is worthy to note that the abundance of fluorescent pseudomonads, in onion soil and rhizosphere, had supported S. maltophilia and to less extent Bacillus spp. The antagonistic potential of $S$. maltophilia against $R$. solanacearum was addressed previously by Messiha et al. (2007b) and Elhalag et al. (2016), both characterized by the production of 


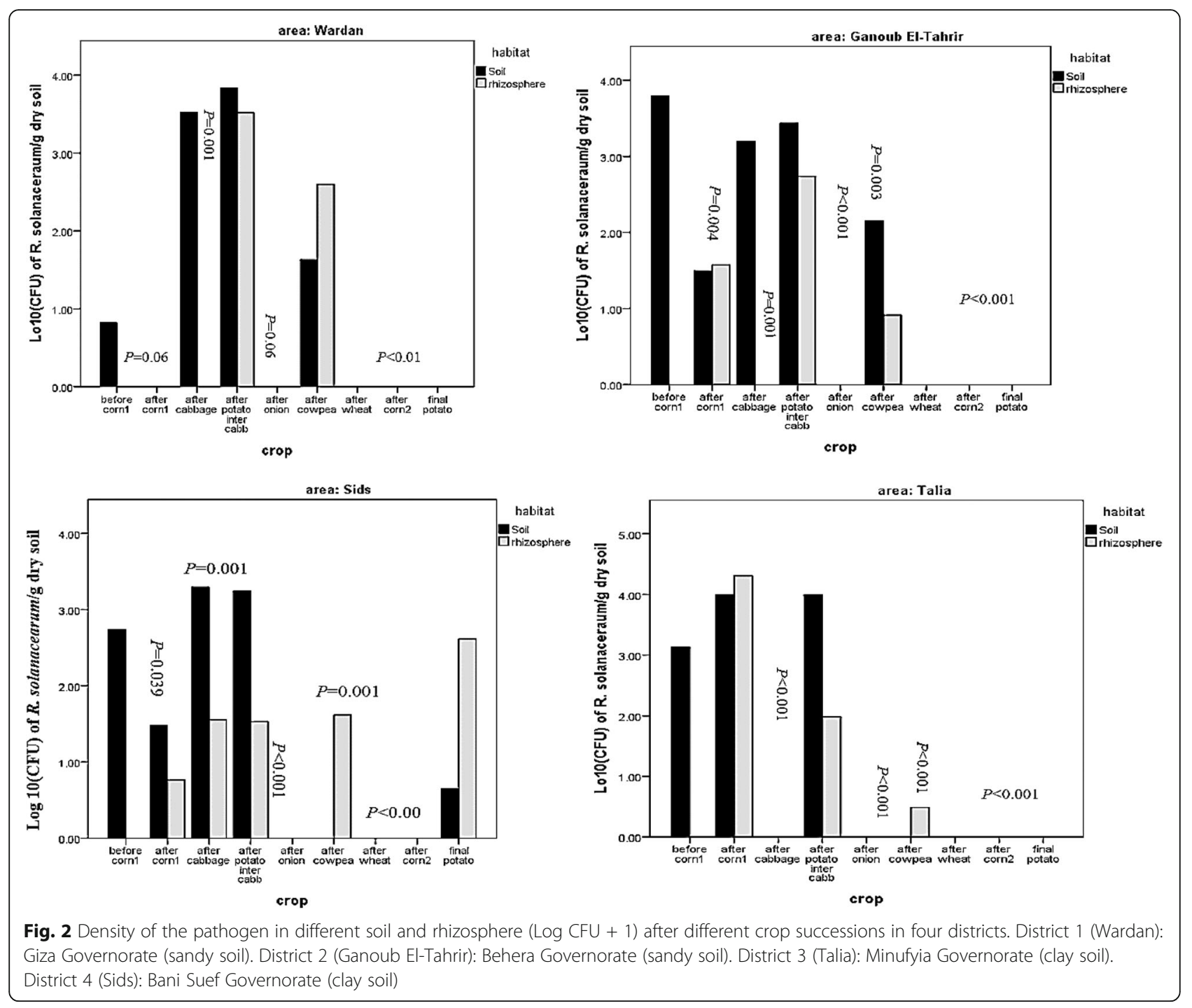

antimicrobial polypeptides, as well as surfactant materials (Raaijmakers et al. 2010).

The pathogen was detected again after planting cowpea, but its density was significantly less than at the beginning of the experiment $(P=0.003)$, being $2.15 \pm 0.4$ for soil and $0.91 \pm 0.6$ for cowpea rhizosphere, where no more bacterial antagonists and the actinomycetes were declined. The pathogen was below the detection level for soil and rhizoshere of wheat and second-year corn $(P<0.001)$. The decline in the pathogen coincided with the increase of actinomycetes in rhizosphere. Moreover, strains resembling D. tsuruhatensis/D. lacustris were detected, and others similar to $S$. maltophilia were detected in wheat rhizosphere. D. lacustris (methylotrophic isolate) showed direct antifungal properties, while its antibacterial potential may be attributed to volatile inhibitory compounds and/or induction of systemic resistance (ISR) (Janahiraman et al. 2016). The pathogen was undetectable in the second-year corn soil and rhizosphere, which coincided with an increase in oligotrophic bacteria along with the detection of a new strain similar to Beijerinckia fluminensis in corn soil. B. fluminensis was recently proven to be a bio-fertilizer as well as a biocontrol agent (EUROPEAN PATENT APPLICATION published in accordance with Art. 153(4) EPC). The corn rhizosphere supported a significant proportion of antagonists, in principal fluorescent pseudomonads (Pseudomonas prosekii and P. fluorescens group), followed by strains of $S$. maltophilia and Burkholderia territorii. $B$. territorii showed an antagonistic potential against the fungal root pathogens as postulated by Riera et al. (2017).

The potato planted at the end of the crop succession program was found pathogen-free in soil, rhizosphere, plant tissues, and potato tubers (Fig. 2). The eradication was associated with oligotrophization in both soil and rhizosphere along with a remarkable increase in proportions of antagonists in potato rhizosphere. Oligotrophism resulted from rotational cropping along with dominance of fluorescent pseudomonas which are 
among the indicators of soil health and disease suppressiveness (van Bruggen and Semenov 2000).

\section{Clay soils}

Talia district The inoculum density of the pathogen in the soil before starting the crop succession was (3.13 \pm 0.5) $\left(\log _{10}+1\right) \mathrm{CFU} / \mathrm{g}$ soil. The pathogen was detected in other congenial plant species namely, Cichorium palmilum (2.0) CFU/g fresh plant; Corchorus olitorius plant (3.61) CFU/g; 3 plants of Cyperus difformis L. (0.77 \pm 0.77) CFU/g, 3 plants of Dinebra retroflexa $(2.3 \pm 0.3), 1$ plant of Portulaca oleracea (3.0) and 10 left over potatoes (Solanum tuberosum) $(2.24 \pm 0.52) \mathrm{CFU} / \mathrm{g}$. The pathogen was not detected in Amaranthus sylvestris, Chenopodium spp., and Stellaria media. The number of congenial plant species as well as volunteer potatoes may explain the density of the pathogen in soil of that district. This district was characterized by a low $\mathrm{C}$ to $\mathrm{N}$ ratio than the other three soils districts. The most common index used to describe soil resource quality is the $\mathrm{C}$ to $\mathrm{N}$ ratio. Low $\mathrm{C}$ to $\mathrm{N}$ soil ratio is generally associated with a greater resource of quality and more rapid rates of decomposition than high $\mathrm{C}$ to $\mathrm{N}$ ratio soils (Esser et al. 2011) and indirectly indicates high microbial activities. Meanwhile, the low $\mathrm{C}$ to $\mathrm{N}$ ratio for this soil may explain the soil conduciveness as postulated by Grunwald (1997). The iron was the most available in that district than in the other districts that decreased the antagonistic potential of fluorescent pseudomonads and siderophores producing bioagents, which are known to dominate below limited iron conditions. The density of the pathogen did not significantly change in soil $(4.0 \pm$ $0.09)$ and in rhizosphere after planting corn $(4.3 \pm 0.13)$. The pathogen density in potato soil was $4.0 \pm 0.09$, which was insignificantly different than the beginning of the experiment, and was $1.98 \pm 0.75$ in rhizosphere intercropped with cabbage, while it was undetectable in cabbage soil $(P=0.001)$. This may be attributed to significant increase in actinomycetes of potato/cabbage soil treatment, and enrichment of endospores in cabbage rhizosphere (compare to potato rhizosphere) in addition to higher antagonists in rhizosphere of both cabbage and potato. The antagonistic strains were identified as $P$. rhizosphaerae, $P$. putida, and $P$. protegens. P. rhizosphaerae are considered strong antagonists against Erwinia amylovora (Paternoster et al. 2010), and P. putida strains are known as growth promoter, biocontrol agent, and recently as biosurfactants (Kruijt et al., 2009). The antagonistic potential of $P$. protegens was attributed to ferric-pyoverdine recognition protein in its membrane. Antagonistic Serratia spp. were also recovered in a recognized level from rhizosphere of both cabbage and potato. The antimicrobial activity of Serratia spp. was attributed to an active antimicrobial compound known as serraticin (Sànchez et al. 2011). Another new biocontrol agent, similar to Perlucidibaca aquatic (possibly not previously recorded as a biocontrol agent), was recovered from the rhizosphere of cabbage. Other strains similar to S. maltophilia and Citrobacter murliniae/C. braakii were recovered from potato rhizosphere. Similar species, C. freundii, was found to produce bacitracin with a broad spectrum antimicrobial activity against gram-negative bacteria (Shanks et al. 2012).

$R$. solanacearum was decreased to undetectable level in onion soil and rhizosphere $(P=0.001)$; this was associated with increasing oligotrophism and endospore ratio along with detection of an antagonist similar to P. aeruginosa in the rhizosphere. The antibacterial potential of $P$. aeruginosa against five bacterial pathogens, including $R$. solanacearum, was addressed by Durairaj et al. (2017). The pathogen was undetectable in cowpea soil $(P=$ $0.001)$ and was $0.49 \pm 0.49$ in rhizosphere of cowpea. Planting cowpea in that district showed short span survival of the pathogen than in the other areas. Cowpea in this area supported a high ratio of antagonistic bacteria, similar to $P$. moorei, P. aeruginosa, and S. maltophilia. Cowpea and corn supported the growth of $S$. maltophilia, which coincided with diminished survival of $R$. solanacearum (Elhalag et al. 2015).

The pathogen was below the detection level for wheat and second corn soil and rhizosphere $(P<0.001)$. The second-year corn soil supported a high ratio of antagonists, such as $S$. maltophilia, Enterobacter asburiae, and Providencia sneebia. Meanwhile, Enterobacter cloacae was recorded ultra-antagonistic against tomato bacterial wilt followed by Bacillus subtilis, Bacillus flexus, and Bacillus pumilus (Thomas and Upreti 2014). Moreover, Providencia sp. was described as a plant growth promoter and biocontrol agent that elicit the wheat defense against different pathogens (Rana et al. 2011). Many Enterobacteriaceae spp. were found to have an antagonistic potential against $R$. solanacearum (Upreti and Thomas 2015).

Potatoes which were planted at the end of the crop succession program were found free of the pathogen in soil, rhizosphere, plant tissues, and potato tubers (Fig. 2). The possible eradication of the pathogen coincided with oligotrophization, noticeable increase in endospores ratio, and high densities of diverse biocontrol agents, such as fluorescent pseudomonads, $S$. maltophilia, Citrobacter freundii, Acinetobacter sp., Delftia sp., and Serratia marcescens. The antagonistic potential of Acinetobacter sp. against $R$. solanacearum was previously addressed by Messiha (2001)

Sids district The pathogen density in soil before starting the crop succession was $(2.74 \pm 0.21)\left(\log _{10}+1\right) \mathrm{CFU} / \mathrm{g}$ soil. It was undetectable in other congenial plant species 
namely, eight Portulaca oleracea plants. The fourth area (Sids) showed a high $\mathrm{C}$ to $\mathrm{N}$ ratio that slow down the OM decomposition by decreasing the soil microbial activity (Shunfeng et al. 2013). Meanwhile, the soils with higher $\mathrm{C}$ to $\mathrm{N}$ ratio are known to be less conducive to soil-borne diseases (Grunwald 1997). The high incidence of the disease may be correlated with the extremely high content of nitrate and sodium salts in soil than in the rest of the areas. The positive correlation between the super soil nitrate and sodium to bacterial wilt incidence was postulated by Messiha et al. (2007a). Significant decrease in density of the pathogen in corn soil $(1.48 \pm 0.44)$ and rhizosphere $(0.76 \pm 0.37)(P=0.039)$ was recorded. The decrease in corn rhizosphere was associated with tendency of increase in fluorescent pseudomonads and increase in actinomycetes in general and different antagonistic Streptomyces strains in particular. Different actinomycetes are known to be excellent antagonists against bacterial pathogens producing more than $50 \%$ of the known antibiotics including streptomycin, neomycin, chloramphenical, and tetracyclines (Kieser et al. 2000).

The pathogen density in potato soil (intercropped with cabbage) and cabbage soil was similar being $3.25 \pm 0.14$ $(P=0.05)$ and $3.3 \pm 0.07$, respectively. They were significantly higher than the beginning of the experiment $(P=$ 0.001 ). The pathogen density in rhizosphere of both potato and cabbage was similar, being $1.53 \pm 0.58$ and $1.56 \pm$ 0.59 , respectively (Fig. 2). Planting potato intercropped with cabbage unexpectedly decreased the pathogen densities in rhizosphere than that in the soil. The latter finding may be with an increase of antagonists in potato and cabbage rhizosphere, similar to $P$. putida, $P$. abietaniphila/P. brassicacearum $/ P$. corrugate/P. migulae, $P$. vranovensis $/ P$. reidholzensis and Bacillus cereus/B. proteolyticus/B. thuringiensis/B. toyonensis/B. wiedmannii/B. paranthracis/B. mobilis/B. pacificus/B. marcorestinctum.

$R$. solanacearum were undetectable in both soil and rhizosphere after onion $(P<0.001)$. Onion soil favored more than $10 \%$ of antagonistic bacteria as fluorescent pseudomonads, followed by S. maltophilia, Bacillus cereus/B. thuringiensis/Streptococcus agalactiae, Ochrobactrum rhizosphaerae. This high ratio of antagonists had declined after planting cowpea; hence, the pathogen was detectable again in cowpea rhizosphere being $1.62 \pm$ 0.81 , which was significantly less than the beginning of the experiment $(P=0.001)$. The pathogen was below the detection level for soil and rhizosphere of wheat and second-year corn $(P<0.001)$. Potatoes which were planted at the end of the crop succession program were infected by the pathogen in soil $(0.65 \pm 0.44)$, rhizosphere (2.62 \pm 0.15$)$ (Fig. 2), and plant tissues (0.37 \pm 0.13 ) and were below the detection level in potato tubers. However, the pathogen was recovered again, but to a less extent than at the beginning of the experiment.
Unlike the three other areas, copiotrophic organisms were dominant and the ratio of actinomycetes, fungi, and fluorescent pseudomonads was neglected in potato soil and rhizosphere, which may explain the failure of pathogen control after the crop rotation in that area. The high percentage of nitrate and sodium ions may explain the increased disease incidence in that area than in the other three areas, as previously postulated by Messiha et al. (2007a).

As general remarks, insignificant difference in $R$. solanacearum population density between soil and rhizosphere was recorded for corn and cowpea. The $R$. solanacearum density decreased into half in cabbage rhizosphere as compared to cabbage soil $(P<0.001)$ and showed $70 \%$ decrease in rhizosphere of potato intercropped with cabbage as compared to potato soil $(P=$ $0.014)$. The pathogen was below the detection level in both soil and rhizosphere of onion, wheat, and second corn in all different areas. The pathogen density in potato rhizosphere was significantly higher than that in potato soil $(P=0.04)$.

\section{Conclusion}

Wheat and onion followed by corn (maize) may be recommended to be used as rotating crop after potato according to the suitable planting season. High organic matter, $\mathrm{Mg}^{+2}, \mathrm{Ca}^{+2}$, and available $\mathrm{K}^{+}$in the clay soils may explain the noticeable disappearance of the disease than in the sandy soils. Meanwhile, the pathogen was detectable again in the soil and rhizosphere of potato in Sids area, most possibly as a result of high sodium content in the soil in this area. Further field investigations and follow-up at different conditions are needed for better conclusion and more accurate generalization.

\section{Supplementary information}

Supplementary information accompanies this paper at https://doi.org/10 1186/s41938-019-0185-x.

Additional file 1. Final potato intercropped with cabbage in Wardan.

Additional file 2. Some antagonists.

Additional file 3. Microbial biodiversity.

\section{Acknowledgements}

The authors are grateful to Prof. Abou Serie Ismail, the previous head of Potato Brown Rot Project (PBRP), for supporting the research activities.

\section{Authors' contributions}

All authors have accepted the final version of the manuscript. All authors read and approved the final manuscript.

\section{Funding}

This article is part of the activities of the project STDF2905 "Environmental friendly program for controlling potato brown rot in Egypt" funded by the Science and Technology Development Fund, Egyptian Ministry for Scientific Research, through a contract between the STDF and the Agricultural Research Center (ARC). 


\section{Availability of data and materials}

The data and material used during the current study are available from the corresponding author on reasonable request.

\section{Ethics approval and consent to participate}

Ethical approval and consent to participate are not required for this study.

\section{Consent for publication}

Not applicable

\section{Competing interests}

The authors declare that they have no competing interests.

\section{Author details}

${ }^{1}$ Bacterial Diseases Research Department, Plant Pathology Research Institute, Agricultural Research Center (ARC), Giza, Egypt. ${ }^{2}$ Potato Brown Rot Project, Ministry of Agriculture, Dokki, Giza, Egypt. ${ }^{3}$ Central Administration of Plant Quarantine, Dokki, Giza, Egypt.

\section{Received: 2 May 2019 Accepted: 29 October 2019}

Published online: 05 December 2019

\section{References}

Akiew S, Trevorrow P (1999) Biofumigation of bacterial wilt of tobacco. In: Margarey RC (ed) Proceedings 1st Australasian Soilborne Disease Symposium Bureau of Sugar Experiment stations, Brisbane, pp 207-208

Bouyoucos GJ (1927) The hydrometer as a new method for the mechanical analysis of soils. Soil Sci 23(5):343-354

Chen Y, Ren X, Zhou X, Huang L, Yan L, Lei Y, Liao B, Huang J, Huang D, Wei W, Jiang $H$ (2014) Dynamics in the resistant and susceptible peanut (Arachis hypogaea L.) root transcriptome on infection with the Ralstonia solanacearum. BMC Genomics 15:1078

Durairaj K, Velmurugan P, Park JH, Chang WS, Park YJ, Senthilkumar P, Choi KM Lee JH, Oh BT (2017) Potential for plant biocontrol activity of isolated Pseudomonas aeruginosa and Bacillus stratosphericus strains against bacterial pathogens acting through both induced plant resistance and direct antagonism. FEMS Microbiol Lett 364(23):fn×225

Elhalag KM, Emara HM, Messiha NAS, Elhadad SA, Abdallah SA (2015) The relation of different crop roots exudates to the survival and suppressive effect of Stenotrophomonas maltophilia (PD4560), Biocontrol Agent of Bacterial Wilt of Potato. J Phytopathol. 163(10):829-840

Elhalag KM, Messiha NAS, Emara HM, Abdallah SA (2016) Evaluation of antibacterial activity of Stenotrophomonas maltophilia against Ralstonia solanacearum under different application conditions. J appl microbiol 120: 1629-1645

Elphinstone JG, Hennessy J, Wilson JK, Stead DE (1996) Sensitivity of different methods for the detection of Ralstonia solanacearum in potato tuber extracts. Bull OEEP/EPPO Bull 26:663-678

Esser G, Kattge J, Sakalli A (2011) Feedback of carbon and nitrogen cycles enhances carbon sequestration in the terrestrial biosphere. Global Change Biol 17:819-842

Estefan G, Sommer R, Ryan J (2013) Methods of soil, plant, and water analysis: a manual for the West Asia and North Africa region third edition. International Center for Agricultural Research in the Dry Areas (ICARDA) 243 pp.

Farag SMA, Elhalag KMA, Hagag MH, Khairy AM, Ibrahim HM, Saker MT, Messiha NAS (2017) Potato bacterial wilt suppression and plant health improvement after application of different antioxidants. J Phytopathol 165:522-537

Francis CK, Connell WB (1913) A colorimetric method for determining hydrocyanic acid in plants, with special reference to kafir corn. In J Am Chem Soc 35(10):1624-1628

Funnell-Harris DL, Sattler SE, Pedersen JF (2013) Characterization of fluorescent Pseudomonas spp. associated with roots and soil of two sorghum genotypes. Eur J Plant Pathol. 136:469-481

Gorissen A, van Overbeek LS, van Elsas JD (2004) Pig slurry reduces the survival of Ralstonia solanacearum biovar 2 in soil. Can J Microbiol 50:587593

Grunwald NJ (1997). Characterization of soil nutrient and microbial variables associated with $P$. aphanidermatum and $R$. solani growth and tomato damping-off during short-term cover crop decomposition. PhD Thesis, University of California at Davis, $190 \mathrm{pp}$.
Haggag WM, Singer SM, Mohamed DEHA (2014) Application of broad-spectrum of marine Streptomyces albidoflavus a biofungicide and plant promoting of tomato diseases. Res J Pharm, Biol Chem Sci 5:142-148

Hayward AC (1991) Biology and epidemiology of bacterial wilt caused by Pseudomonas solanacearum. Annu Rev phytopathol 29:65-87

Hiddink GA, Termorshuizen AJ, Raaijmakers JM, van Bruggen AHC (2005) Effect of mixed and single crops on disease suppressiveness of soils. Phytopathol 95: $1325-1332$

Hoitink HAJ, Boehm MJ (1999) Biocontrol within the context of soil microbial communities: a substrate-dependent phenomenon. Annu Rev Phytopathol 37:427-446

Janahiraman V, Anandham R, Kwon SW, Sundaram S, Karthik Pandi V, Krishnamoorthy R, Kim K, Samaddar S, As T (2016) Control of wilt and rot pathogens of tomato by antagonistic pink pigmented facultative methylotrophic Delftia lacustris and Bacillus spp. Front Plant Sci 7:1-11

Jones R, Barbetti M (2012) Influence of climate change on plant disease infections and epidemics caused by viruses and bacteria. CAB Reviews: Perspectives in Agriculture, Veterinary Science, Nutrition and Natural Resources, 7: 1-31.

Karim Z, Hossain MS (2018) Management of bacterial wilt (Ralstonia solanacearum) of potato: focus on natural bioactive compounds. J Biodivers Conserv Bioresour Manag. 4(1)

Katafiire M, Adipala E, Lemaga B, Olanya M, El-bedewy R (2005) Management of bacterial wilt of potato using one-season rotation crops in southwestern Uganda. In: Allen C, Prior P, Hayward AC (eds) Bacterial Wilt Disease and the Ralstonia solanacearum Species Complex. American Phytopathological Society Press, St Paul, MN, pp 197-204

Kieser T, Bibb MJ, Buttner MJ, Chater KF Hopwood DA (2000a) General Introduction to Actinomycete Biology Practical Streptomyces Genetics. 1st Edn., John Innes Foundation, Norwich, England, ISBN: 0-7084-0623-8, pp: 118.

Lemaga B, Kanzikwera R, Kakuhenzire R, Hakiza J, Manzi G (2001) The effect of crop rotation on bacterial wilt incidence and potato tuber yield. Afr Crop Sci J. African crop science society, Kampala. Uganda. 9:257-266

Lindsay WL, Norvell WA (1978) Development of a DTPA soil test for zinc, iron, manganese and copper. Soil Sci Soc Am J 42:421-428

Löbmann MT, Vetukuri RR, de Zinger L, Alsanius BW, Grenville-Briggs L, Walter A (2016) The occurrence of pathogen suppressive soils in Sweden in relation to soil biota, soil properties, and farming practices. Appl. Soil Ecol. 107:57-65

Messiha NAS (2001) Studies on biological control of potato brown rot disease Msc. Thesis, Department of Botony, Fac.of Science. Zagazg Univ.

Messiha NAS, van Bruggen AHC, van Diepeningen AD, de Vos OJ, Termorshuizen AJ, NNA T-T-S, Janse JD (2007a) Potato brown rot incidence and severity under different management and amendment regimes in different soil types. Eur J Plant Pathol 119:367-381

Messiha NAS, van Diepeningen AD, Farag NS, Abdallah SA, Janse JD, van Bruggen AHC (2007b) Stenotrophomonas maltophilia: a new potential biocontrol agent of Ralstonia solanacearum, causal agent of potato brown rot. Eur J Plant Pathol 118:211-225

Messiha NAS, van Diepeningen AD, Janse JD, Termorshuizen AJ, SchoemanWeerdesteijn ME, Franz E, van Bruggen AHC (2009) Survival of Ralstonia solanacearum is affected more by soil type than by management. Appl Soi Ecol. 43:206-215

Messiha NAS (2006) Bacterial wilt of potato (Ralstonia solanacearum race 3 , biovar2): disease management, pathogen survival and possible eradication. $\mathrm{PhD}$ thesis Wageningen University, The Netherlands

Mwaniki PK, Wagara IN, Birech R, Kinyua ZM, E.Schulte-Geldermann E, Freyer B (2017). Impact of crop rotation sequences on potato in fields inoculated with bacterial wilt caused by Ralstonia solanacearum. Afr J Agric Res. 12(14): 1226-1235

Norman DJ, Chen J, Yuen JMF, Mangravita-Novo A, Byrne D, Walsh L (2006) Control of bacterial wilt of geranium with phosphorous acid. Plant Dis. 90 : 798-802

Osbourn AE (1996) Preformed antimicrobial compounds and plant defense against fungal attack. Plant Cell 8:r8zr-rr83

Park SY, Kang HO, Jang HS, Lee JK, Koo BT, Yum DY (2005) Identification of extracellular $\mathrm{N}$-acylhomoserine lactone acylase from a Streptomyces sp. and its application to quorum quenching. App Environ Microbiol 71:2632-2641

Paternoster T, Défago G, Duffy B, Gessler C, Pertot I (2010) Selection of a biocontrol agent based on a potential mechanism of action: degradation of nicotinic acid, a growth factor essential for Erwinia amylovora. Int Microbiol 13:195-206 
Prior P, Fegan M (2005) Recent developments in the phylogeny and classification of Ralstonia solanacearum. Acta Hort (ISHS) 695:127-136

Raaijmakers JM, De Bruijn I, Nybroe O, Ongena M (2010) Natural functions of lipopeptides from Bacillus and Pseudomonas: more than surfactants and antibiotics. FEMS Microbiol Rev 34(6):1037-1062

Raaijmakers JM, Weller DM, Thomashow LS (1997) Frequency of antibiotic producing Pseudomonas spp. in natural environments. Appl Environ Microbiol 63:881-887

Ran LX, Liu CY, Wu GJ, van Loon LC, Bakker PAHM (2005) Suppression of bacterial wilt in Eucalyptus urophylla by fluorescent Pseudomonas spp. in China. Biol Control 32:111-112

Rana A, Saharan B, Kabi SR, Prasanna R, Nain L (2011) Providencia, a PGPR with biocontrol potential elicits defense enzymes in wheat. Annu Plant Protect Sci 19(1):138-141

Reddy PP (2017) Agro-ecological approaches to pest management for sustainable agriculture. Springer, Singapore

Riera N, Handique U, Zhang Y, Dewdney MM, Wang N (2017) Characterization of antimicrobial-producing beneficial bacteria isolated from Huanglongbing Escape citrus trees Front microbial, vol 8, p 2415

Sànchez LA, Hedström M, Delgado MA (2011) Delgado OD (2011) Production, purification and characterization of serraticin $\mathrm{A}$, a novel cold-active antimicrobial produced by Serratia proteamaculans 136. J Appl Microbiol 109(3):936-945

Shanks RMQ, Dashiff A, Alster JS, Kadouri DE (2012) Isolation and identification of a bacteriocin with antibacterial and anti-biofilm activity from Citrobacter freundii Arch. Microbiol. 194(7):575-587

Sharma JP, Kumar S (2004) Effect of crop rotation on population of Ralstonia solanacearum in tomato wilt sick soil. India phytopathology .Indian phytopathological society, New Delhi, India.57: 80-81.

Shunfeng G, Haigang X, Mengmeng J, Yuanmao J (2013) Characteristics of soil organic carbon, total nitrogen, and $\mathrm{C} / \mathrm{N}$ ratio in Chinese apple orchards. Open J Soil Sci 3:213-217

Stanger TF, Lauer JG (2008) Corn grain yield response to crop rotation and nitrogen over 35 years. Agron J 100(3):643-650

Termorshuizen AJ, van Rijn E, van de Gaag DJ, Chen Y, Lagerlof J, Paplomatas EJ, Ramert B, Steinberg C, Zmora S (2006) Disease suppression of 18 composts against 7 pathogens. Soil Biol Biochem 38:2461-2477

Thomas P, Upreti R (2014) Testing of bacterial endophytes from non-host sources as potential antagonistic agents against tomato wilt pathogen Ralstonia solanacearum. Adv Microbiol 4:656-666

Upreti R, Thomas P (2015) Root-associated bacterial endophytes from Ralstonia solanacearum resistant and susceptible tomato cultivars and their pathogen antagonistic effects. Front Microbiol 6:255

van Bruggen AHC, Semenov AM (2000) In search of biological indicators for soil health and disease suppression. App Soil Ecol 15:13-24

van Bruggen AHC, Termorshuizen AJ (2003) Integrated approaches to root disease management in organic farming systems. Australas Plant Pathol 32:141-156

Waite RD, Curtis MA (2009) Pseudomonas aeruginosa PAO1 pyocin production affects population dynamics within mixed-culture biofilms. J Bacteriol 191:1349-1354

Walkely A, Black IA (1934) An examination of the Degtjareff method for determining soil organic matter, and a proposed modification of the chromic acid titration method. Soil Sci 37:29-38

Wang WZ, Morohoshi T, Someya N, lkeda T (2012) Diversity and distribution of Nacylhomoserine lactone (AHL)-degrading activity and $\mathrm{AHL}$-lactonase (AiiM) in genus Microbacterium. Microbes Environment 27(3):330-333

Weller SA, Elphinstone JG, Smith NC, Boonham N, Stead DE (2000) Detection of Ralstonia solanacearum strains with a quantitative, multiplex, real-time, fluorogenic PCR (TaqMan) assay. Appl Environ Microbiol 66(7):2853-2858 Yan $J$ (1993) Influence of plant growth regulators on turfgrass polar Lipid, tolerance to drought and saline stress

Williams JS, Cooper RM (2004) The oldest fungicide and newest phytoalexin - a reappraisal of the fungi toxicity of elemental sulphur. Plant Pathol 53:263-279

Yabuuchi E, Kosako Y, Yano I, Hotta H, Nishiuchi Y (1995) Transfer of two Burkholderia and an Alcaligenes species to Ralstonia gen. nov.: Proposal of Ralstonia pickettii (Ralston, Palleroni and Douderoff 1973) comb. nov, Ralstonia solanacearum (Smith 1896) comb. nov. \& Ralstonia eutropha (Davis 1969) comb. Nov. Microbiol Immunol 39:897-904

\section{Publisher's Note}

Springer Nature remains neutral with regard to jurisdictional claims in published maps and institutional affiliations.

\section{Submit your manuscript to a SpringerOpen ${ }^{\circ}$ journal and benefit from:}

- Convenient online submission

- Rigorous peer review

- Open access: articles freely available online

High visibility within the field

- Retaining the copyright to your article

Submit your next manuscript at $\boldsymbol{\nabla}$ springeropen.com 